\title{
POTENSI BIOAKTIVITAS ANTI JAMUR DAN ANTI-UV DARI ISOLAT JAMUR SIMBION PADA ASCIDIA Eudistoma sp
}

\author{
(Antifungal and Anti-Uv Bioactivity Potential from Symbiont Fungi in Ascidia Eudistoma sp.)
}

\author{
Enjelika Polimba Sahuma', Deiske A. Sumilat', Veibe Warow'1, Fitje Losung', Esther D. \\ Angkouw' ${ }^{1}$, Okstan Kalesaran'
}

1. Mahasiswa Program Studi IImu Kelautan, FPIK, UNSRAT Manado

2. Staf Pengajar Program Studi IImu Kelautan, FPIK, UNSRAT Manado

3. Staf Pengajar Program Studi Budidaya Perairan, FPIK UNSRAT Manado

Penulis korespondensi: Enjelika Polimba Sahuma; angelicapolimbasahuma@gmail.com

\begin{abstract}
Ascidia Eudistoma sp. produce bioactive compounds that can inhibit the growth of microorganisms. Ascidians are also known for their potential secondary metabolites in the biomedical world. This study aimed to obtain isolates of the ascidia symbiont Eudistoma sp., determine the antifungal activity against the test fungus Candida albicans, and determine the anti-UV activity of the symbiont Eudistoma sp. The ascidia symbiont fungus was extracted using maceration method with ethyl acetate solvent and tested for antifungal activity using the test fungus Candida albicans. The antifungal activity test results showed that the diameter of the AFBN $5 \mathrm{~b}$ inhibition zone of $9 \mathrm{~mm}$. The symbiont fungus can be said to have potential as an antifungal drug. Testing the anti-UV activity of fungi in symbiosis with ascidia Eudistoma sp. using a spectrophotometer showed that the extract sample of the ascida symbiont fungus could produce an absorption at UV-B $(\lambda 290-320 \mathrm{~nm})$ of 3.8 absorbance and when compared to UV-A ( $\lambda$ $370-400 \mathrm{~nm}$ ) an absorption value of 0.38 was obtained and is still classified as moderate
\end{abstract}

Keywords: Ascidia, Eudistoma sp., symbionts, Antifungal and Anti-UV

Ascidia Eudistoma sp. menghasilkan senyawa bioaktif yang mampu menghambat pertumbuhan mikroorganisme. Ascidia juga dikenal karena keberadaan metabolit sekundernya yang sangat potensial dalam dunia biomedis. Penelitian ini bertujuan untuk mendapatkan isolat jamur simbion ascidia Eudistoma sp., menentukan aktivitas anti jamur terhadap jamur uji Candida albicans, menentukan aktivitas anti-UV dari jamur simbion Eudistoma sp., Jamur simbion ascidia tersebut diekstrak menggunakan metode maserasi dengan pelarut etil asetat dan dilakukan pengujian aktivitas antijamur menggunakan jamur uji Candida albicans, hasil uji aktivitas antijamur menunjukkan diameter zona hambat AFBN 5b sebesar $9 \mathrm{~mm}$. Sehingga bisa dikatakan jamur simbion tersebut berpotensi sebagai bahan pembuatan obat antijamur. Pengujian aktivitas anti-UV dari jamur yang bersimbion dengan ascidia Eudistoma sp. menggunakan spektofotometer menunjukan bahwa sampel esktrak jamur simbion ascida dapat menghasilkan serapan pada UV-B $(\lambda$ 290-320 nm) sebesar 3,8 absorban dan jika dibandingkan dengan pada UV-A $(\lambda 370-400 \mathrm{~nm})$ nilai serapan 0,38 yang didapatkan masih tergolong sedang.

Kata Kunci: Ascidia, Eudistoma sp., simbion, Antijamur dan Anti-UV

\section{PENDAHULUAN}

Lingkungan laut merupakan sumber yang besar dari produk alam yang memiliki struktur yang unik umumnya terkonsertrasi pada sponge,tunikata, bryozoa dan moluska yang merupakan organisme yang hidup dalam kolom air. Sejumlah besar dari senyawa ini menunjukan aktivitas farmakologi yang kuat dan merupakan kandidat yang menarik untuk bahan obat-obatan baru terutama pada area penelitian antikanker dan antimikroba (Bara et al., 2015).

Ascidia adalah avertebrata laut yang termasuk dalam subfilum Urochordata (Tunicata). Organisme ini menjadi sangat penting karena mereka berkontribusi banyak bagi stabilitas ekosistem laut dengan menyediakan lahan subur bagi sejumlah fauna air, bagian dari rantai makanan, dan mangsa bagi banyak 
hewan laut (Ali et al., 2011; Shenkar \& Swalla, 2011).

Kelas Ascidiacea adalah salah satu kelompok avertebrata bentik yang dominan di banyak komunitas sesil laut. Keragaman Ascidia di seluruh dunia benar-benar menakjubkan. Saat ini, lebih dari 3000 spesies Ascidia telah dideskripsikan di semua habitat laut. Mereka ditemukan dari daerah tropis ke kutub dan dari air dangkal ke laut dalam (Shenkar et al., 2012). Ascidia merupakan sumber bahan alami yang menarik dan memiliki aktivitas biologis. Berbagai macam metabolit sekunder diproduksi Ascidia untuk menghindari pemangsaan dan penempelan organisme (Watters et al., 2018).

Keragaman Ascidia di suatu tempat tergantung pada ketersediaan dan keragaman substrat keras, salinitas, dan suhu (Gab-Alla et al., 2008; Primo \& Vázquez, 2009), sedangkan kepadatan populasi Ascidian tergantung pada ketersediaan makanan (partikel organik tersuspensi dalam air) (Shenkar \& Loya, 2009). Ascidia adalah organisme filter feeder yang berperan dalam pengendalian fitoplankton di perairan (Lambert et al, 2007) dan dapat mengurangi eutrofikasi atau konsentrasi kontaminan (Draughon et al., 2010).

Ascidian juga dikenal karena keberadaan metabolit sekundernya yang sangat potensial dalam dunia biomedis (Erba et al., 2001). Ascidia menjadi tempat hidup bagi berbagai komunitas mikroba yang merupakan sumber tambahan produk alami yang bersifat sitotoksik, antimikroba, antioksidan, anti inflamasi dan masih banyak lagi (Casertano et al., 2020). Chen et al. (2018) melaporkan bahwa 8\% metabolit sekunder dari ascidia faktanya diproduksi oleh mikroorganisme simbion. Jamur yang berasal dari laut diketahui memproduksi senyawa metabolit sekunder baru yang memiliki aktivitas biologis (Hasan et al., 2015). Kebanyakan dari metabolit sekunder yang berasal dari jamur laut sangat sukar didapatkan pada jamur yang hidup di darat. Penelitian yang dilakukan oleh Montolalu et al,. (2021) melaporkan bahwa Ascidia jenis Eudistoma sp. bersimbion dengan jamur
Schizophyllum commune. memiliki bioaktivitas antibakteri dan antioksidan.

Beberapa tahun terakhir, penelitian tentang ascidia semakin berkembang dan mengarah pada isolasi metabolit sekunder dengan aktivitas biologis yang kuat. Beberapa laporan menunjukkan bahwa pada ascidia telah ditemukan berbagai senyawa bioaktif yang memiliki potensi aktivitas antitumor/ antikanker (Tatsuta et al., 2017; Sumilat et al., 2018; Watters, 2018). Akan tetapi, ekstraksi organisme laut secara besar-besaran bertentangan dengan kepentingan konservasi (Bara et al., 2015; Sumilat et al, 2018; Sumilat et al., 2019; Casertano et al., 2020), dan berpotensi mengganggu keseimbangan pada ekosistem di perairan (Pastra et al., 2012).

Jamur adalah eukariota heterotrof yang mendapatkan nutriennya melalui penyerapan (absorption). Selain memiliki dampak yang merugikan, jamur juga memiliki banyak manfaat, diantaranya sebagai bahan makanan dan beberapa jamur mikroskopik ada pula yang bersimbiosis dengan tumbuhan maupun hewan dan menghasilkan senyawa metabolit yang dapat digunakan sebagai antibiotika (Campbell dkk. 2003). Salah satu mikroorganisme laut yang mulai banyak diteliti karena potensinya dalam bidang kesehatan adalah jamur yang hidup berasosiasi dengan organisme lain (Harvell et al., 2000). Burgessa et al., (2003) mengemukakan bahwa mikroorganisme yang bersimbiosis dengan organisme laut memiliki kemampuan mensintesa metabolit sekunder seperti inangnya.

Spektroskopi UV merupakan teknik yang didasarkan pada penyerapan cahaya oleh sampel atau senyawa yang tidak diketahui. Cahaya diserap secara parsial bergantung pada masing-masing senyawa, dan cahaya yang tersisa direkam sebagai fungsi panjang gelombang oleh detector (Caro, 2017) Spektoskopi ultra violet (UV) digunakan untuk mengukur jumlah ikatan rangkap atau konyugasi aromatik dalam suatu molekul, dimana panjang gelombang cahaya UV jauh lebih pendek daripada panjang gelombang IR, 
satuan panjang gelombang UV adalah nano meter (nm) (Supratman, 2010).

\section{METODE PENELITIAN}

\section{Waktu dan Lokasi Penelitian}

Penelitian dilakukan selama \pm 3 bulan, dimulai pada bulan Januari 2020 hingga bulan Maret 2020. Untuk kegiatan isolasi sampel, kultur jamur, ekstraksi, serta pengujian aktivitas antijamur dilakukan di Laboratorium Biomolekuler dan Farmasetika Laut, Fakultas Perikanan dan IImu Kelautan, Universitas Sam Ratulangi. Untuk pengujian aktivitas antiUV menggunakan alat UV Spektrofotometer dilakukan di Divisi Mikrobiologi, Laboratorium Farmasi, Fakultas Matematika dan IImu Pengetahuan Alam, Universitas Sam Ratulangi.

\section{Penanganan Sampel dan Identifikasi Sampel Ascidia}

Sampel ascidia Eudistoma sp. yang digunakan merupakan sampel yang dikoleksi dari perairan Bunaken, Manado, Sulawesi Utara. Sampel yang diperoleh dibilas menggunakan air laut steril sebanyak $3 x$ dengan tujuan untuk membersihkan kotoran yang menempel di permukaan sampel. Sampel kemudian disimpan dalam wadah bersih dan dibawa ke laboratorium untuk perlakuan selanjutnya.

Identifikasi sampel ascidia Eudistoma sp. dipandu dengan buku "Tropical Pasific Invertebrates" oleh Colin dan Anerson (1995) dengan mengamati morofologinya melalui bentuk, tekstur, warna, posisi zooid dan kloaka.

\section{Alat dan Bahan}

Alat yang digunakan dalam penelitian ini yakni Laminar air flow, Autoklaf, Rotary Vacuum Evaporator (Eyela), Timbangan, Lampu Bunsen, Erlenmeyer, Cawan petri disk, Corong filtrasi, Gelasukur/measuring cylinder, Kamera Handphone, Tube plastic, Tabung reaksi, Mikropipet, Sarung tangan, Kertas saring/filter paper, Kertas label, alumunium foil, Masker, Jarum Ose, Pinset, Mistar,
Kertas cakram/paper disc, Tisu, Spatula, Spektrofotometer UV-Vis (Shimadzu), Plastik parafilm, Plastik zip lock, Rak tabung reaksi, Masker medis, Lampu UV, dan Labu evaporator, Kuvet.

Bahan yang digunakan seperti Candida albicans, Agar, Air laut saring 50\%, Akuades (OneMed), Etanol 70\%, Etil asetat, Ekstrak daging (Difco), Metanol, Pepton (Bacto), Potato Dextrose Agarl PDA (HiMedia), Ascidia Eudistoma sp, Metanol 95\%, Metanol 20\%, dan Metanol $20 \%$.

\section{Sterilisasi Alat dan Bahan}

Sterilisasi merupakan cara untuk mendapatkan suatu keadaan yang bebas dari kontaminasi mikroba. Alat-alat seperti cawan petri, labu erlenmeyer, tabung reaksi serta pisau dan spatula disterilkan dengan cara dimasukkan dalam oven pada suhu $150^{\circ} \mathrm{C}$ selama 120 menit. Alat-alat seperti kertas cakram dan tip serta bahan berupa media cair dan padat, disterilkan menggunakan autoklaf pada suhu $121^{\circ} \mathrm{C}$ dan tekanan $1 \mathrm{~atm}$ selama 20 menit.

\section{Pembuatan media PDA (Potato Dextrose Agar)}

Media padat PDA ditimbang sebanyak 3,9 gram, dan dimasukkan dalam gelas erlenmeyer kemudian dilarutkan menggunakan air laut saring $50 \%$ sebanyak $100 \mathrm{ml}$, setelah itu ditutup dengan aluminium foil untuk disterilkan. Media disterilkan dengan menggunakan autoklaf pada suhu $121^{\circ} \mathrm{C}$ selama 15 menit, kemudian diaduk dengan cara menggoyangkan secara perlahan setelah itu dituang ke dalam cawan petri.

\section{Isolasi dan Kultur Jamur Simbion Ascidia}

Isolasi sampel Ascidia dilakukan di dalam laminary air flow dengan cara sampel dari Ascidia direndam pada etanol $70 \%$ selama 1-2 menit untuk sterilisasi permukaan sampel. Kemudian sampel Ascidia dipotong-potong kecil. Sampel Ascidia ditanam pada cawan petri, kegiatan ini dilakukan dalam keadaan aseptis di laminar air flow. Cawan petri 
tersebut dibungkus menggunakan plastik wrap dan diinkubasi pada suhu ruangan selama $3 \times 24$ jam.

Jamur mulai tumbuh di sekitar sampel setelah inkubasi, dan jamur-jamur tersebut dikultur secara berulang pada media PDA hingga didapatkan isolat murni jamur. Kultur jamur dilakukan dengan mengambil jamur yang tumbuh menggunakan pisau dan ditanam pada media PDA yang baru. Seluruh kegiatan isolasi hingga ekstraksi menggunakan panduan dalam Kjer (2010) dengan beberapa modifikasi.

\section{Pembuatan Media Nasi}

Media nasi dibuat dengan menggunakan beras (dua merpati) yang dicuci bersih sebanyak tiga kali. Setiap labu Erlenmeyer berukuran $250 \mathrm{ml}$ diisi dengan beras 50 gram dan masukan air laut saring sebanyak $60 \mathrm{ml}$ air laut saring $50 \%$, setelah itu ditutup menggunakan alumunium foil dan dibiarkan selama $1 \times 24$. Selanjunya, disterilkan dengan autoklaf pada suhu $121^{\circ} \mathrm{C}$ selama 20 menit. Setelah selesai dimasak dan disterilkan, maka media nasi tersebut diinkubasi pada suhu ruangan selama 5 hari.

\section{Kultur Jamur pada Media Nasi}

Setelah jamur dikultur pada media PDA murni, maka selanjutnya jamur-jamur tersebut akan dikultur pada media nasi yang sudah diinkubasi selama $5 \times 24$ jam. Isolat murni jamur yang tumbuh pada media PDA dipindahkan ke media nasi dengan memotong media yang tertutupi dengan jamur. Inkubasi dilakukan selama 14 hari hingga jamur tumbuh pada media nasi.

\section{Pembuatan Media Cair B1}

Dalam pembuatan media cair B1 disiapkan beberapa bahan seperti Pepton 0,25 gram, meat extract 0,15 gram, natrium klorida 0,15 gram dan akuades sebanyak $100 \mathrm{ml}$ kemudian diaduk sampai homogen. Setelah itu ditutup menggunakan aluminium foil dan disterilkan menggunakan autoklaf pada suhu $121^{\circ} \mathrm{C}$ selama 15 menit. Setelah media cair B1 disterilisasi kemudian dinginkan selama 15 menit, setelah itu media cair B1 dituang pada petri yang sudah disterilkan. Kemudian media cair B1 diinkubasi pada suhu ruangan selama $1 \times 24$ jam.

\section{Ekstraksi Jamur Simbion Ascidia}

Jamur-jamur yang telah tumbuh pada media nasi akan dihancurkan menggunakan pengaduk kaca. Selanjutnya, dimaserasi menggunakan pelarut etil asetat sebanyak tiga kali. Maserat disaring menggunakan kertas saring dan corong Buchner, sehingga didapatkan filtrat. Pelarut etil asetat pada filtrat diuapkan menggunakan rotary vacuum evaporator pada suhu $40^{\circ} \mathrm{C}$, sehingga didapatkan ekstrak kasar yang diambil menggunakan micropipet dan dimasukkan ke dalam tabung reaksi dan diberi penanda (label).

\section{Pembuatan Media Padat B1}

Media pengujian antijamur B1 padat dibuat dengan melarutkan $0,1 \mathrm{gram}$ pepton, 0,6 gram $\mathrm{NaCl}$, ekstrak daging 0,6 dan 2 gram agar dalam $200 \mathrm{ml}$ akuades. Media disterilkan menggunakan autoklaf, kemudian didinginkan pada suhu ruang selama \pm 15 menit.

\section{Pembuatan kontrol}

Kontrol positif pada penelitian ini menggunakan ketoconazole sebagai tolak ukur zona hambat ekstrak isolat jamur, sedangkan kontrol negatif menggunakan metanol p.a yang dipakai untuk melarutkan ekstrak kering. Kontrol positif dibuat dengan melarutkan $250 \mathrm{mg}$ ketoconazole

\section{Pengujian Anti Jamur}

Pada pengujian aktivitas antijamur digunakan sediaan ekstrak jamur simbion Eudistoma sp. dengan konsentrasi 10.000 ppm, kontrol positif menggunakan obat kloramfenikol dan kontrol negatif menggunakan pelarut metanol p.a. Masing-masing larutan ditotolkan pada kertas cakram berdiameter $6 \mathrm{~mm}$ sebanyak $20 \mu \mathrm{l}$. Kertas cakram diletakkan pada media uji dan diinkubasi pada suhu ruang selama $1 \times 24$ jam. Pengamatan dilakukan setelah $1 \times 24$ jam dan $2 \times 24$ jam 
masa inkubasi. Pengukuran diameter zona hambat menggunakan mistar dan kontrol positif digunakan sebagai pembanding.

\section{Pengujian aktivitas Anti-UV}

Pengujian anti-UV diuji pada UV spektofotometer bertujuan untuk mengetahui apakah jamur simbion ascidia tersebut memiliki senyawa anti-UV. Dilakukan pengenceran pada ekstrak kasar 0,5 ml diencerkan dengan metanol $20 \%$ sebanyak $2 \mathrm{ml}$ kemudian hasil pengenceran dimasukkan dalam suprasil kuvet, pada kuvet yang satunya dimasukkan pelarut metanol $20 \%$ sebagai blanko. Kemudian diuji pada alat UV spektofotometer dengan rentang panjang gelombang 290-500 nm. Selanjutnya, diamati banyaknya sinar yang diabsorbsi dan ditentukan apakah nilai absorban yang dihasilkan termasuk dalam senyawa antiUV A atau anti-UV B.

\section{HASIL DAN PEMBAHASAN}

\section{Hasil identifikasi Ascidia}

Sampel Ascidia yang digunakan dalam penelitian ini setelah diidentifikasi secara morfologi dengan cara membandingkan warna, bentuk dan tekstur menggunakan buku panduan Colin dan Arneson (1995). Diketahui bahwa Ascidia tersebut merupakan Ascidia Eudistoma sp.

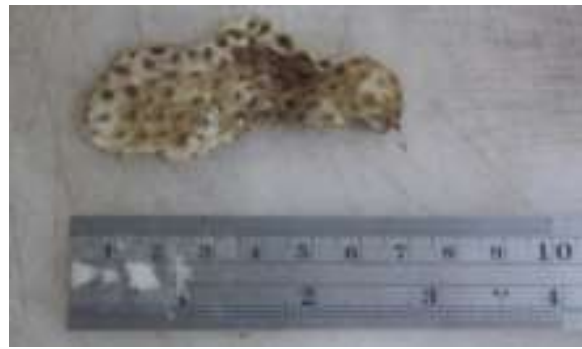

Gambar 1. Sampel ascidia Eudistoma sp.

\section{Hasil Isolasi dan kultur jamur}

Hasil isolasi dan kultur jamur simbion didapatkan isolat AFBN $5 b$ sebagai jamur yang bersimbion dengan ascidia Eudistoma sp. Isolasi dan kultur yang dilakukan secara berulang hingga didapatkan isolat murni seperti pada Gambar 2. Isolat AFBN 5b memiliki ciri-ciri morfologi yaitu misel berwarna putih dan berserabut.
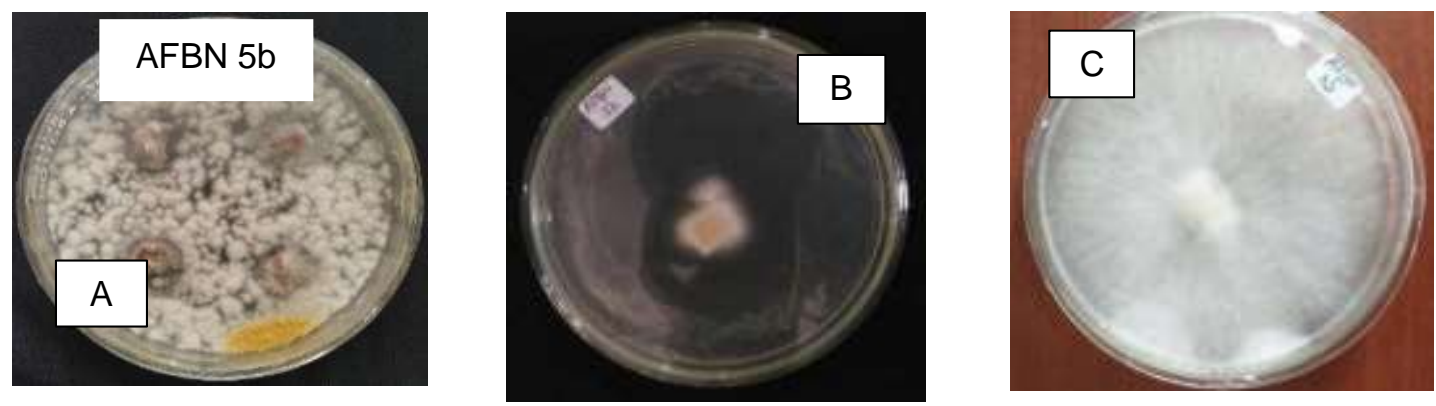

Gambar 2. Hasil Isolasi Ascidia Eudistoma sp. (a), proses kultur dan pemurnian isolat jamur (b), isolat ascidia AFBN 5b (c).

\section{Hasil Kultur Jamur Pada Media Nasi}

Setelah dikultur pada media nasi selama 5 hari isolat jamur AFBN $5 b$ yang bersimbion dengan ascidia Eudistoma sp. menunjukkan pertumbuhan pada media nasi seperti pada gambar 3. Ciri-ciri jamur yang bertumbuh pada media nasi yaitu miselium berwarna putih dan berserabut. Miselium pada media nasi telah tumbuh menyebar hingga kebagian bawah tabung erlenmyer yang berisi nasi.

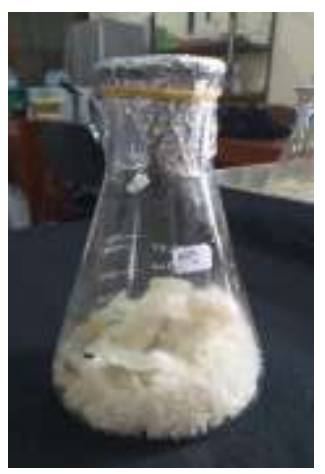

Gambar 3. kurtur jamur pada media nasi diinkubasi $7 \times 24$ jam. 


\section{Hasil Ektraksi Jamur Simbion}

Hasil dari ekstraksi isolat jamur AFBN $5 b$ yang bersimbion dengan ascidia Eudistoma sp. memiliki warna ekstrak coklat (gambar 4), total ekstraksi sebanyak $3 \mathrm{ml}$, dan berat kering ekstrak sampel sebanyak 0,719 gram.

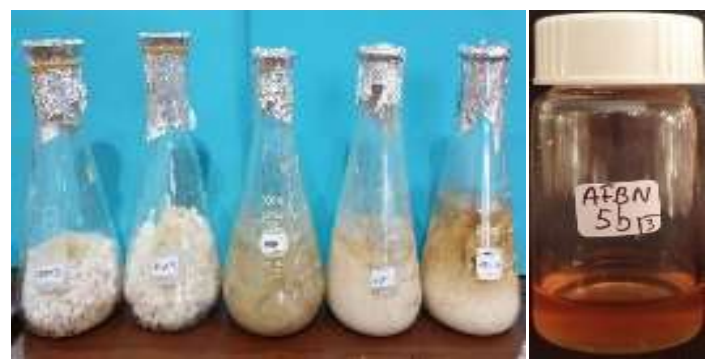

Gambar 4. Hasil maserasi etil asetat jamur simbion dan Hasil ekstrak kasar

\section{Hasil Pengujian Anti Jamur}

Adanya aktivitas antijamur dilihat berdasarkan zona bening yang ada di sekitar kertas cakram (gambar 9). Pengamatan dilakukan dengan mengukur zona bening tersebut menggunakan mistar. Pengamatan dilakukan setelah $1 \times 24$ jam dan $2 \times 24$ jam inkubasi. Hasil pengamatan setelah inkubasi $1 \times 24$ jam dan 2x24 jam didapatkan zona hambat ekstrak isolat jamur AFBN $5 b$ dengan nilai rata-rata $8,67 \mathrm{~mm}$. Sebagai pembanding, kontrol (+) menunjukkan diameter hambatan sebesar $14 \mathrm{~mm}$ terhadap Candida albicans pada masa inkubasi $1 \times 24$ jam dan meningkat menjadi $15 \mathrm{~mm}$ untuk Candida albicans setelah inkubasi $2 \times 24$ jam. Sedangkan kontrol negatif tidak menghambat pertumbuhan jamur uji selama 2x24 jam.
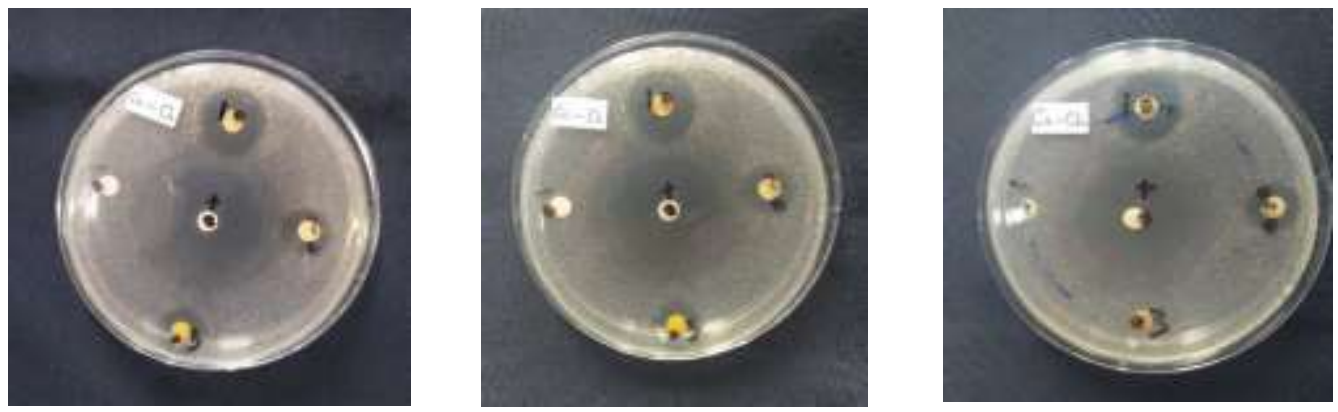

Gambar 5. Hasil Pengujian Antijamur dari Eudistoma sp. pada Media Candida albicans.

Table 1. Rerata zona hambat ekstrak jamur simbion ascidian, ekstrak etil asetat dan kontrol terhadap pertumbuhan jamur candida albicans.

\begin{tabular}{|c|c|c|c|}
\hline \multirow{2}{*}{ KODE SAMPEL } & \multirow{2}{*}{ ULANGAN } & \multicolumn{2}{|c|}{ JAMUR UJI } \\
\cline { 2 - 4 } & & $1 \times 24$ & $2 \times 24$ \\
\cline { 2 - 4 } & 1 & 9 & 9 \\
\hline \multirow{3}{*}{ AFBN 5b } & 2 & 10 & 10 \\
\cline { 2 - 4 } & 3 & 8 & 8 \\
\hline \multirow{2}{*}{$\begin{array}{c}\text { Kontrol (+) } \\
\text { (Ketoconazole) }\end{array}$} & 1 & 14 & 14 \\
\cline { 2 - 4 } & 2 & 13 & 14 \\
\hline \multirow{2}{*}{$\begin{array}{c}\text { Kontrol (-) } \\
\text { (Etil Asetat) }\end{array}$} & 3 & 13 & - \\
\cline { 2 - 4 } & 1 & - & - \\
\hline
\end{tabular}

Melalui data yang ditampilkan pada (tabel 1) dapat dilihat bahwa zona hambat yang dihasilkan dari ekstrak kasar Ascidia terhadap jamur Candida albicans memiliki nilai yang bervariasi namun cenderung lebih rendah nilainya jika dibandingkan 
dengan zona hambat pada kontrol (+) (ketoconazole). kekuatan aktivitas anti jamur dapat digolongkan sebagai berikut, diameter zona hambat $\leq 5 \mathrm{~mm}$ (lemah), 5$10 \mathrm{~mm}$ (sedang), 10-20 mm (kuat) dan > $20 \mathrm{~mm}$ (sangat kuat). Menurut Cappucino and Natalia (2001) mengemukakan bahwa besar kecilnya daerah hambatan dipengaruhi oleh beberapa faktor seperti laju pertumbuhan mikroorganisme, kemampuan dan laju difusi bahan aktif pada medium, kepekaan mikroorganisme terhadap zat aktif serta ketebalan dan viskositas medium.

Dari rerata zona hambat pada (tabel 1) pada jamur Candida albicans yang diperoleh maka diketahui ekstrak isolat AFBN $5 \mathrm{~b}$ menghasilkan rerata sebesar $9 \mathrm{~mm}$ dari inkubasi selama $1 \times 24$ dan $2 \times 24$, yang menunjukan sampel menghasilkan aktivitas anti jamur zona hambat yang tergolong sedang.

Efisiensi yang lebih tinggi oleh ketoconazole dibandingkan dengan ekstrak isolat jamur Pada penelitian yang dilakukan kontrol (+) memiliki zona hambat yang lebih besar dibandingkan dengan ekstrak isolat jamur AFBN $5 b$ terhadap jamur uji Candida albicans. Penggunaan kontrol (+) pada penelitian ini adalah antibiotik ketoconazole yang telah diketahui memiliki spektrum kerja yang luas dalam menghambat pertumbuhan/infeksi jamur.

Kontrol (-) yang digunakan adalah etil asetat karena pelarut yang digunakan untuk melarutkan larutan uji adalah etil asetata. Dari hasil yang ditunjukkan, kontrol (-) tidak memiliki zona hambat pada jamur sehingga dapat diketahui bahwa aktivitas anti jamur yang ditunjukkan oleh ekstrak ascidia Eudistoma sp. adalah murni senyawa aktif yang terkandung dalam sampel. Dapat dipastikan juga bahwa pelarut yang dipakai sebagai kontrol (-) tidak memberikan pengaruh pada zona hambat yang terbentuk.

\section{Pengujian Aktivitas Anti-UV}

Ascidia Eudistoma sp. diujikan menggunakan alat UV-1800 SHIMADZU spektrofotometer untuk mengetahui serapan sampel pada panjang gelombang 290-400 nm.

\begin{tabular}{|c|c|}
\hline $\begin{array}{c}\text { Panjang } \\
\text { gelombang }\end{array}$ & $\begin{array}{l}\text { Hasil pengujian } \\
\text { aktivitas anti-UV }\end{array}$ \\
\hline $\begin{array}{l}\text { Serapan pada } \\
\lambda 290-320 \mathrm{~nm}\end{array}$ & $\begin{array}{l}\text { (UV-B) Sebesar } \\
\text { 3,8 absorban }\end{array}$ \\
\hline $\begin{array}{l}\text { Serapan pada } \\
\wedge 320-400 \mathrm{~nm}\end{array}$ & $\begin{array}{l}\text { (UV-A) Sebesar } \\
0,38 \text { absorban }\end{array}$ \\
\hline
\end{tabular}

Tabel 3. Hasil pengujian aktivitas anti-UV

Menurut Tahir dkk, (2008) Senyawa anti-UV adalah senyawa yang memiliki paparan sinar UV A $(\lambda=320-400$ $\mathrm{nm})$, dan UV B $(\lambda=290-320 \mathrm{~nm})$, UV C $(\lambda=$ $200-290 \mathrm{~nm}$ ). Analisis panjang gelombang ekstrak jamur AFBN 5b menggunakan alat spektrofotometer pada panjang gelombang UV A $(\lambda=320-400 \mathrm{~nm})$, dan UV B $(\lambda=$ 290-320 nm), menghasilkan satu puncak dapat dilihat pada gambar 10. Dan berdasarkan pengujian melalui spektofotometer menunjukan hasil bahwa esktrak jamur simbion AFBN 5b Eudistoma sp. mampu mengabsorbsi UV-A dan UV-B, nilai serapannya bervariasi dan ada penurunan sehingga nilanya pada UV-A hanya sebesar 0,38 absorban.

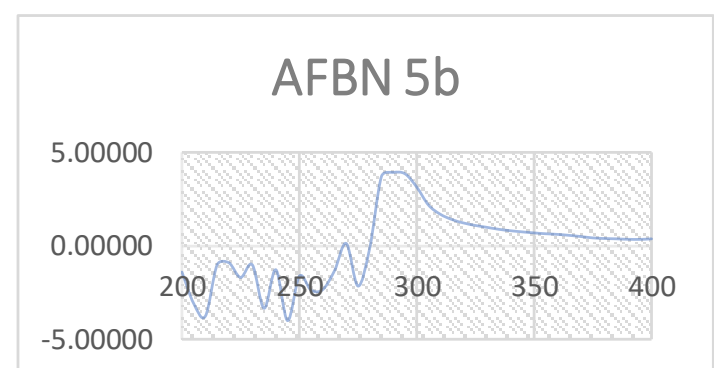

Gambar 6. Hasil spektrofotometer sampel ekstrak jamur simbion Ascidia Eudistoma $\mathrm{sp}$.

Hasil yang didapat dari pengujian spektrofotometer menunjukkan bahwa ekstrak ascidia simbion memiliki substansi anti-UV. Senyawa anti-UV yang dihasilkan diduga merupakan bentuk adaptasi organisme ini terhadapan paparan radiasi UV, yang kemudian senyawa ini dapat diterapkan oleh manusia sebagai bahan pembuatan tabir surya yang berpotensi melawan ataupun mengurangi pengaruh buruk dari radiasi UV. Beberapa organisme laut yang hidup pada daerah perairan dangkal maupun daerah pasang surut 
ditemukan memiliki senyawa organik yang bersifat sebagai anti-UV yaitu Mycosporine-like amino acids (MAAs) (Dunlap \& Shick, 1998).

Berdasarkan dari data
spektrofotometer yang diperoleh ekstrak jamur simbion Eudistoma sp. AFBN $5 b$ memiliki absorbansi sebesar (UV-B) 3,8 absorban dan (UV-A) sebesar 0,38 absorban. Hal ini menunjukkan bahwa jamur yang bersimbion dengan Eudistoma sp. memiliki potensi dalam menghasilkan bioaktivitas anti-UV.

\section{KESIMPULAN}

Berdasarkan hasil penelitian yang dilakukan maka dapat disimpilkan bahwa:

1. Didapatkan satu isolat jamur dengan kode AFBN 5b yang bersimbion dengan ascidia Eudistoma sp.

2. Berdasarkan hasil pengamatan diameter hambatan isolat jamur AFBN 5b memiliki aktivitas antijamur terhadap jamur uji Candida albicans dengan nilai rata-rata yaitu $8,67 \mathrm{~mm}$.

3. Pengujian anti-UV menggunakan spektofotometer menunjukan bahwa sampel esktrak jamur simbion ascida menghasilkan serapan pada UV-B ( $\lambda$ 290$320 \mathrm{~nm}$ ) sebesar 3,8 absorban dan jika dibandingkan dengan pada UV-A ( $\lambda$ 370$400 \mathrm{~nm}$ ) nilai serapan 0,38.

\section{DAFTAR PUSTAKA}

Bara R. A., G. D. Kandou., A R. B. Ola., dan J. Posangi. 2015. Analisis Senyawa Antibiotik dari Jamur Simbion yang Terdapat dalam Ascidias Didemnum mole di Sekitar Perairan Bunaken-Sulawesi Utara. Jurnal LPPM Bidang Sains dan Teknologi. 2(2), hal 28-35

Ali, H. A. J dan M. Tamilselvi. 2016. Ascidians in Coastal Water: A Compehensive Inventory of Ascidian Fauna from the Indian Coast. Switzerland: Springer International Publishing.

Casertano, M., M. Mena dan C. Imperatore. 2020. The AscidianDerived Metabolites with
Antimicrobial Properties.

Antibiotics, 9, 510: 1-30.

Chen. L., J. Hu, J. Xu, C. Shao dan G. Wang. 2018. Biological and Chemical Diversity of AscidianAssociated Microorganism. Marine Drugs, 16, 362: 1-33.

Montolalu, G., Sumilat, D. A., Rumampuk, N. D., Rumengan, I. F., Lintang, R. A., \& Kreckhoff, R. L. 2021. Isolasi Jamur Simbion Ascidia Schizophyllum commune yang Memiliki Aktivitas Antibakteri. Jurnal Pesisir Dan Laut Tropis, 9(1), 22-29.

Shenkar, N. 2012. Ascidian (Chordata, Ascidiancea) diversity in the Red Sea. Marine Biodiversity, 42(4): 459-469.

Watters, D. J. 2018. Ascidian Toxins with Potential for Drug Development. Marine Drugs, 16, 162: 1-33.

Gab-Alla, A.A.F.A. 2008. Distribution of the sea squirt EcteinAscidian thurstoni Herdman, 1890 (Ascidiancea: Perophoridae) along Suez Canal and Egyptian Red Sea coasts. Oceanologia, 50(2), 239-253.

Shenkar, N., \& Loya, Y. 2009. Nonindigenous Ascidianns (Chordata: Tunicata) along the Mediterranean coast of Israel. Marine Biodiversity Records, 2, 17.

Lambert, G. 2007. Invasive sea squirts: A growing global problem. Journal of Experimental Marine Biology and Ecology, 342(1), 3-4.

Erba, E., Bergamaschi, D., Bassano, L., Damia, G., Ronzoni, S., Faircloth, G. T., \& D'Incalci, M. 2001. Ecteinascidin-743 (ET-743), a natural marine compound, with a unique mechanism of action. European Journal of Cancer, 37(1), 97-105.

Tatsuta, T, M. Hosono, H. Rotinsulu, D. S. Wewengkang, D. A. Sumilat, M. Namikoshi dan H. Yamazaki. 2017. Lissoclibadin 1, a Polysulfur Aromatic Alakloid from the Indonesian Ascidian Lissoclinum cf. badium, Induces Caspase 
Dependent Apoptosis in Human Colon Cancer Cells and

Sumilat, D.A., Wewengkang, D.S., Rotinsulu, H., Yamazaki, H., Oda, T., Ukai, K., Namikoshi, M. 2018. Bioactivity of extracts from ascidians collected in North Sulawesi as seeds of marinederived drugs. AACL Bioflux. 11(2): 516-524
Watters, D. J. 2018. Ascidian Toxins with Potential for Drug Development. Marine Drugs, 16, 162: 1-33.

Pastra, D. A, Melki dan H. Surbakti. 2012. Penapisan Bakteri yang Bersimbion dengan Spons Jenis Aplysina sp sebagai Penghasil Antibakteri dari Perairan Pulau Tegal Lampung. Maspari Journal, 4 (1): 77-82 